\title{
BACKGROUND OF U AND Th IN SEDIMENTS OF BEDROCK RIVERS
}

Miguel Ángel Álvarez-Vázquez ${ }^{1 *}$; ; Elena de Uña-Álvarez ${ }^{2}$; Ricardo Prego ${ }^{3}$

\section{Abstract}

The Miño River is a good example of bedrock rivers, where sediment geochemistry is scarcely studied. Its urban reach when passing through the city of Ourense gathers some characteristics that provide interest to its sediments, like scarcity of fine sediments accumulation and the impact of several human activities. Sediments trapped by potholes and other rock cavities were considered. In order to evaluate society-nature interactions through sediment composition it is critical to determine the compositional background (in absence of human alterations), particularly when working with trace elements. This work presents an exploratory assay to determine background in sediments from bedrock rivers by using two uncommon elements, uranium (U) and thorium (Th). To determine their background different statistical techniques were applied in order to set the background composition value and calculate possible enrichments. Background was calculated by simple least squares lineal regression by using $\mathrm{Al}$ as independent variable (reference element) resulting in $8.7 \mathrm{mgU}$ $\mathrm{kg}-1$ and $5.6 \mathrm{mgTh} \mathrm{kg}-1$. Enrichments were found in some particular samples and can be attributed to intrinsic microenvironment complexities inside rock cavities.

Keywords: Bedrock rivers. Background estimation. Actinoids. Geochemistry.
${ }^{1}$ Environmental scientist, post-doctoral researcher at the University of Vigo, Ourense, Spain. GEAAT Research Group, Area of Physical Geography.

Corresponding author: mianalva@uvigo.es

${ }^{2}$ Physical Geographer, Full Professor at University of Vigo, Ourense, Spain. GEAAT Research Group, Area of Physical Geography.

${ }^{3}$ Inorganic Chemist and Chemical Oceanographer, Research Professor. Spanish Research Council, Marine Research Institute (IIM-CSIC), Vigo, Spain. 


\section{Introduction}

F luvial sediments have been used for environmental assessment, assuming they are representative of the condition of the river in the time when they were deposited (SANTSCHI et al., 2001). The study of sediment composition through the contents on major, minor and trace elements has proved to be a powerful tool for environmental assessment. Trace elements are of particular interest as geochemical tracers of human influence, some of them are intimately linked to many human activities (ICON, 2001) and, because of their very low contents in the environment, a low human input may cause a significant (measurable) change in their composition. Varieties of empirical and statistical techniques were developed in order to separate the natural contents of trace elements and the possible anthropogenic load (DUNG et al., 2013; BIRCH, 2017). The combination of background functions at a local scale, followed by the assessment through local enrichment factors has showed a good performance (GRYGAR and POPELKA, 2016), if they are supported by an expert based knowledge evaluation (ÁLVAREZ-VÁZQUEZ et al., 2020).

However, the environmental study of sediment composition was mainly performed in well-developed floodplains, estuaries and coastal areas. There is a lack of knowledge in the study of sediments from small rivers, headwater rivers and bedrock rivers, where the accumulation of sediments is scarce. Bedrock rivers, as a general term, are rivers where the rock outcrop in riverbed and banks is exposed or covered by a relatively thin layer of sediments, being actively incising the Earth crust and, hence, intensively modelling the landscape (WHIPPLE et al., 2013). All the exposed motivate a critical scientific question: Is it possible to directly apply currently developed methodologies for separation of geochemical signals to bedrock rivers sediments?

Uranium (U) and Thorium (Th) are trace elements in geogenic matrices, their average contents in the upper continental crust are 10.5 and $2.7 \mathrm{mg} \mathrm{kg}-1$, respectively (RUDNICK and GAO, 2003). These two elements are the primordial elements of the actinoids group (i.e. existing in their current form since before the Earth was formed). Alike all the actinoids, $\mathrm{U}$ and $\mathrm{Th}$ are radioactive and, hence, elements of concern (PLANT and SAUNDERS, 1996). Their release to the environment is mainly from rock weathering, and anthopogenic inputs can occur due to nuclear industry, mining and metallurgy of $U$, coal combustion and fertilizers (LOCUTURA RUPÉREZ et al., 2012). Their anthropogenic presence in environmental samples is not expected (except in defined areas). Therefore, they are suitable to test methodologies for background estimation, first and crucial step for environmental assessment. Accordingly, the aim of this work is to test the applicability of local background estimation through background functions and the subsequent assessment based on the calculation of local enrichment factors.

\section{Material and Methods}

The selected reach of the Miño/Minho River (Fig. 1) is about $4 \mathrm{~km}$ long from, upstream, the medieval bridge in the heart of the city of Ourense ( $75 \mathrm{~m}$ width), to the thermal facilities of "O Muiño da Veiga", downstream (395 m width). The average slope of the reach is below $0.1 \%$, flowing over the bedrock and allowing the progressive accumulation of boulders, pebbles and sand with the increasing widening. The retention of fine sediments within the river channel is restricted to rock cavities like sculpted forms, between other bigger clasts and in small depositional areas.

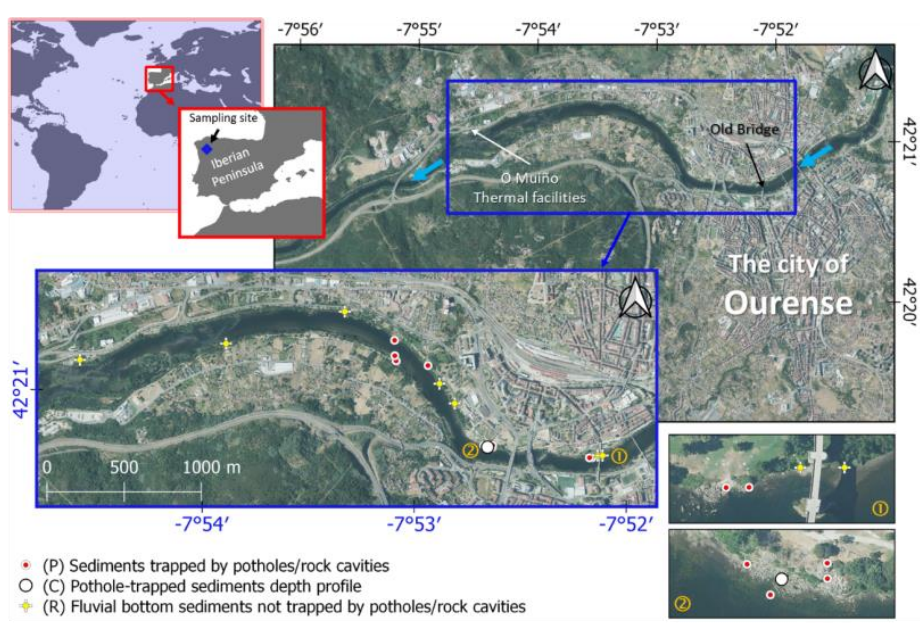

Figure 1. Location map of sampling site and samples. Basemap from PNOA ortophotos (IGN). Figure made with QGIS software.

While studying the value as geoheritage of potholes (ÁLVAREZ-VÁZQUEZ and DE UÑA-ÁLVAREZ, 2017a), it was observed that potholes in the area could retain permanent sedimentary deposits when the maximum depth is higher than $40 \mathrm{~cm}$ (ALLVAREZ-VÁZQUEZ and DE UÑA-ÁVAREZ, 2017b), shallower sculpted forms are expected to retain sediments only between flooding periods when water is not flowing over them. In this area the river flows over granitic (variscan) rocks (Geology from the 204GE map from IGME-Xunta de Galicia), first calc-alkaline and then alkaline granitoids, around the boundary between the two rock types small intrusions of metamorphic rocs (schists and metavulcanites) can be found. Flanking the river channel there are some Quaternary (Holocene) alluvial deposits retained by soils developed over narrow floodplains or covered by artificial surfaces (urban is the prevailing soil coverage/use in the area). Population density is high, being an urban reach flowing throughout 
the city of Ourense, and it is estimated in about 1250 inhab km-2.

Sediment samples were withdrawn in three differentiated environments: (i) surface sediments trapped in potholes and other rock cavities (samples P\#, $n=12$ ), (ii) a depth profile (core) of permanent sediments trapped in a pothole and sampled every $2 \mathrm{~cm}$ (samples $\mathrm{CH}, \mathrm{n}=12$ ) and, (iii) river surface sediments not trapped in rock cavities (samples R\#, $n=7$ ). Sample location is presented in Fig. 1. Sediments were collected with a plastic spatula and stored in plastic zip-bags. Once in the laboratory, samples were oven dried at $45 \pm 5^{\circ} \mathrm{C}$ until constant weight, and the fine fraction $(<0.063 \mathrm{~mm})$ was separated by sieving. The fine fraction was selected for the analysis that was performed by inductively coupled plasma optical emission spectrometry (ICP-OES; i.e. $\mathrm{Al}, \mathrm{Ca}, \mathrm{Fe}, \mathrm{Mg}, \mathrm{Mn}, \mathrm{Sc}$ and $\mathrm{Y}$ ) and inductively coupled plasma mass spectrometry (ICPMS; i.e. $U$ and Th) in the Center for Scientific and Technological Research Support (CACTI - University of Vigo), ISO 9001 certified laboratory. The results for Th were calculated by the instrument factory-calibration settings.

The dataset was processed with the Statgraphics Centurion 18 software (c) Statgraphics Technologies, Inc.), and further spatial analysis was performed with QGIS 3.4.11-Madeira (GNU license).

\section{Results}

\subsection{Characterization of samples and exploratory statistics}

Mainly coarse sediment composes the samples. The median values are $47.6 \%$ sand (particle size between 2 and $0.063 \mathrm{~mm}$ ) and $29.2 \%$ gravels ( $>2 \mathrm{~mm}$ ). The fine fraction of sediments $(<0.063 \mathrm{~mm})$, used for assessment in this study, is scarce, its median value is $0.5 \%$ with data between a 0.02 and a $5.9 \%$. Considering only the $<2 \mathrm{~mm}$ fraction, fines are always below a $7 \%$ with a median value of $1.15 \%$. By differentiating the three sample types, i.e. (P) surface sediment samples trapped in potholes and other rock cavities, $(C)$ depth profile $(22 \mathrm{~cm})$ of sediments trapped into a pothole, and $(\mathrm{R})$ river surface sediments not trapped in rock cavities; the abundance of fine sediments (median value) in decreasing order is as follows: $R(2.9)>C(0.6)>P(0.3)$.
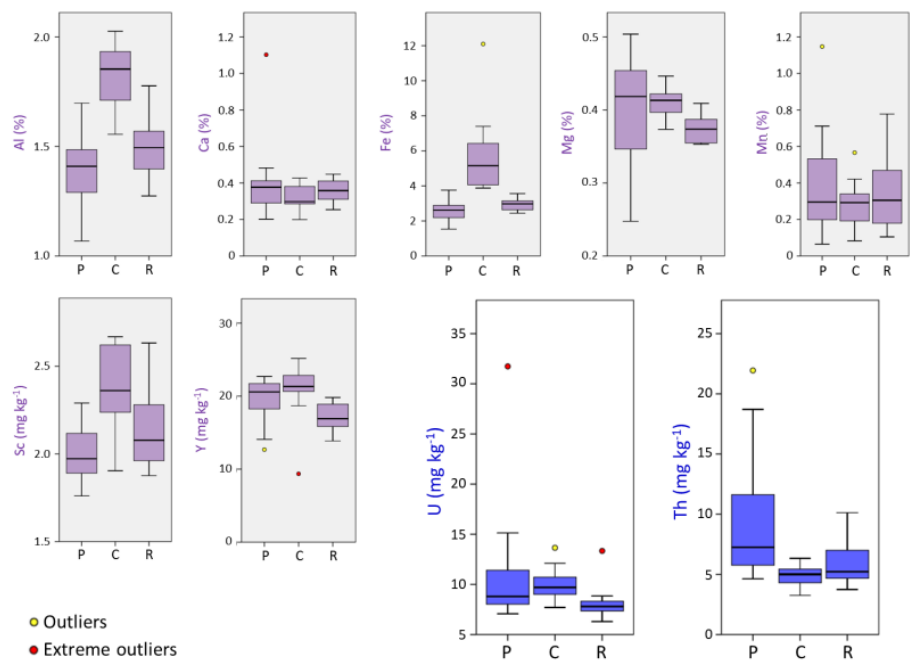

- Extreme outliers
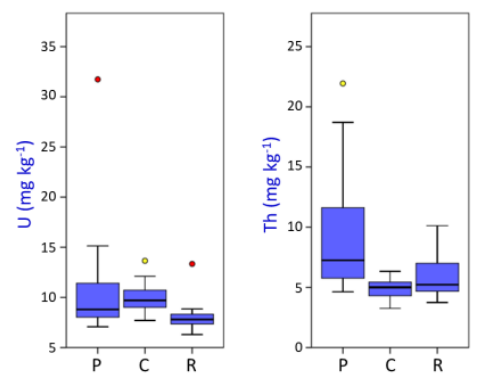

Figure 2. Box-plots of data distribution for explanatory variables (i.e. $\mathrm{Al}, \mathrm{Ca}, \mathrm{Fe}, \mathrm{Mg}, \mathrm{Mn}, \mathrm{Sc}$ and $\mathrm{Y}$ ) and target variables (Th and $U$ ). Separated by contents of surface sediments trapped by potholes and rock cavities $(P)$, depth profile of sediments trapped by a pothole (C) and surface bottom river sediments not trapped by rock cavities (R).

Geochemical composition of elements analysed in the sediment samples (potentially explanatory variables: Al, $\mathrm{Ca}, \mathrm{Fe}, \mathrm{Mg}, \mathrm{Mn}$, Sc and $\mathrm{Y}$; and target elements: $\mathrm{U}$ and $\mathrm{Th}$ ) is summarized in Fig. 2. Both data series $(U$ and $T h$ contents) presented standardized skewness and standardized kurtosis outside the range -2 to +2 (Table 1 ); thus it can be assumed that there is a significant departure for normality for data distribution of both elements and, in consequence, non-parametric robust statistics were applied in the first data exploration. Data distribution statistics are presented in Table 1. To avoid the influence of extreme values in the following data treatment, an iterative identification and deletion of outliers was performed until no outliers were identified in the dataset. Outliers (i.e. extreme values that can statistically belong to another different population) were identified according to the Tukey's inner fences. That is, values outside the range between $\mathrm{Q} 1-1.5 \mathrm{Q} \cdot \mathrm{QR}$ and Q3+1.5.IQR; where Q1 and Q3 are the quartiles 1 (25\% percentile) and 3 (75\% percentile) respectively, IQR is the difference of the values representing Q1 and Q3 (i.e. IQR $=\mathrm{Q} 3-\mathrm{Q} 1$ ).

Exploring the $U$ data distribution 6 outliers were detected and, hence, deleted by the moment. These samples were P01 (31.7 mg kg-1), P08 (15.1), C09 (13.6), R02 (13.3), P03 (13.0) and C08 (12.1). Respective to Th, the detected and deleted outliers were 5, to wit P03 (21.9 mg kg-1), P09 (18.7), P08 (12.7), P12 (10.5) and R03 (10.1). After removing these values, the new database presented standardized skewness and standardized kurtosis within the range -2 to +2 , in consequence the new dataset (hereinafter subset) comes from a normal distribution. Statistics characterizing this dataset are presented in 
Table 2. The outliers were removed in order to simplify the dataset and perform background assessment but, they are relevant and will be assessed further.

Table 1. Robust exploratory statistics of the complete dataset of Th and $U$ contents.

\begin{tabular}{lrr}
\hline & $\mathrm{U}$ & Th \\
\hline Count $(\mathrm{n})$ & 31 & 31 \\
Q1 (p25) & 7.8 & 4.6 \\
Median- Q2 (p50) & 8.9 & 5.5 \\
Q3 (p75) & 10.5 & 7.3 \\
Minimum & 6.3 & 3.3 \\
Maximum & 31.7 & 21.9 \\
Range & 25.4 & 19.7 \\
Stnd. skewness & 8.8 & 5.8 \\
Stnd. kurtosis & 20.2 & 7.5 \\
\hline
\end{tabular}

According to the empirical rule, the distributions assuming normality can be expressed as mean \pm 2 standard deviations, creating a range with a probability of the $95 \%$ of any value within the population will fall inside it. These ranges are $8.6 \pm 2.4 \mathrm{mgU} \mathrm{kg}-1$ and $5.4 \pm 2.4 \mathrm{mgTh} \mathrm{kg}-1$.

\subsection{Reference element, background levels and local enrichment factors}

Some major constituents (i.e. Al, Ca, Fe and $\mathrm{Mg}$ ) and other elements (i.e. $\mathrm{Mn}, \mathrm{Sc}$ and $\mathrm{Y}$ ) were checked in order to find the best reference to interpret the contents of $U$ and $T$. By using the subset (after deletion of outliers), the Pearson product-moment correlation was considered (Fig. 3). Uranium ant Th contents were correlated (statistically significant non-zero correlation at the $95 \%$ confidence level, $\mathrm{P}$-value < 0.05) as follows: $\mathrm{U}$ and $\mathrm{Sc}(0.67), \mathrm{U}$ and $\mathrm{Al}$ (0.65), and Th and Al (-0.51).

\begin{tabular}{|c|c|c|c|c|c|c|c|c|c|}
\hline & 1,0 & & & & & & 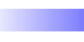 & & 1,0 \\
\hline Al & & $-0,12$ & 0,58 & 0,51 & $-0,08$ & 0,78 & 0,58 & 0,65 & $-0,51$ \\
\hline $\mathrm{Ca}$ & $-0,12$ & & $-0,29$ & 0,48 & 0,82 & $-0,30$ & 0,26 & $-0,19$ & $-0,25$ \\
\hline $\mathrm{Fe}$ & 0,58 & $-0,29$ & & 0,24 & $-0,21$ & 0,24 & $-0,11$ & 0,39 & $-0,22$ \\
\hline & 0,51 & 0,48 & 0,24 & & 0,53 & 0,11 & 0,60 & 0,02 & $-0,09$ \\
\hline & $-0,08$ & 0,82 & $-0,21$ & 0,53 & & $-0,46$ & 0,31 & $-0,32$ & $-0,26$ \\
\hline Sc & 0,78 & $-0,30$ & 0,24 & 0,11 & $-0,46$ & & 0,47 & 0,67 & $-0,19$ \\
\hline & 0,58 & 0,26 & $-0,11$ & 0,60 & 0,31 & 0,47 & & 0,38 & $-0,27$ \\
\hline & 0,65 & $-0,19$ & 0,39 & 0,02 & $-0,32$ & 0,67 & 0,38 & & $-0,07$ \\
\hline & $-0,51$ & $-0,25$ & $-0,22$ & $-0,09$ & $-0,26$ & $-0,19$ & $-0,27$ & $-0,07$ & \\
\hline & $\overline{4}$ & U్ర & ثீ & $\sum^{0}$ & 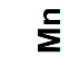 & ن & $>$ & $\supset$ & $\stackrel{2}{r}$ \\
\hline
\end{tabular}

Figure 3. Pearson product-moment correlations between the studied variables.

The background estimation was performed as a background function obtained by least squares simple regression between the target element (dependent variable, i.e. $U$ and $T h$ ) and a reference element (independent variable, Al and Sc were tested, Fig. 3).

According to the results of the Pearson product-moment correlation, $\mathrm{U}$ was directly correlated with $\mathrm{Sc}$ and $\mathrm{Al}$, thus, a regression was performed and unusual residuals were iteratively deleted until no unusual residuals were present in the data distribution. Unusual residuals are defined as those which model predicted value differs more than 2 standard deviations from the measured value (Studentized residuals). The regression functions between $\mathrm{U}(\mathrm{mg} \cdot \mathrm{kg}-1)$ and SC (mg.kg-1) and $\mathrm{U}(\mathrm{mg} \cdot \mathrm{kg}-1)$ and $\mathrm{Al}(\%)$ are presented in Eq. 1 and Eq. 2 respectively (Fig. 4A and 4B).

(Eq. 1) $U B G=2.36+2.97 \cdot S C(R=0.76, n=22$, Fig. $4 A)$

(Eq. 2) UBG $=3.39+3.34 \cdot \mathrm{Al}(\mathrm{R}=0.81, \mathrm{n}=21$, Fig. $4 \mathrm{~B})$

At the view of the coefficient of correlation (R) the simple (least squares) regression between $\mathrm{Al}$ and $\mathrm{U}$ (Eq. 2) was selected as background function.
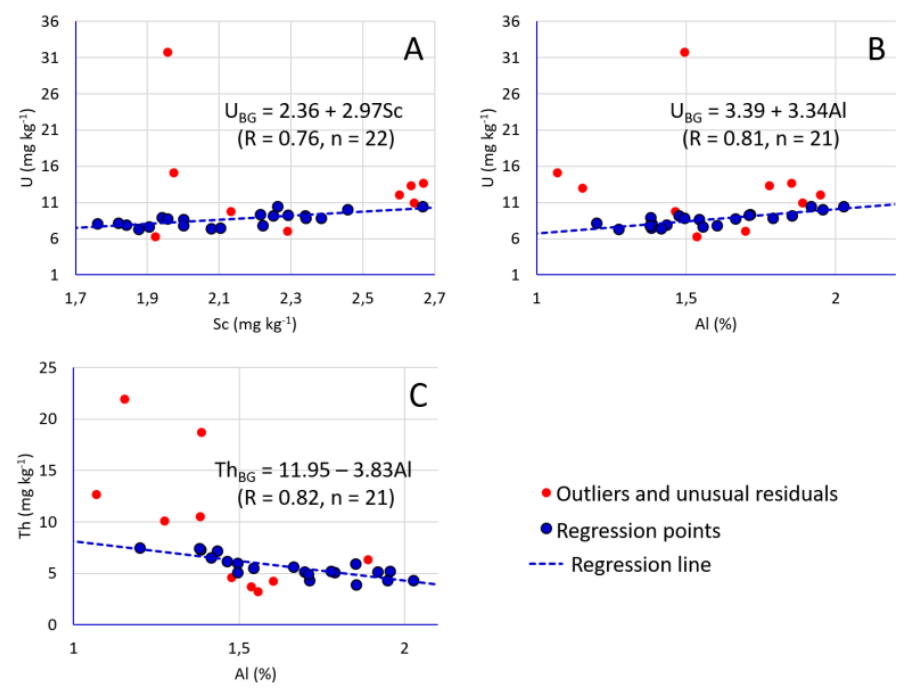

$$
\begin{aligned}
& \text { - Outliers and unusual residuals } \\
& \text { - Regression points } \\
& \text {---- Regression line }
\end{aligned}
$$

Figure 4. Biplots presenting the regression between target elements (Th and $\mathrm{U}$ ) versus reference elements ( $\mathrm{Al}$ and Sc).

Thorium was correlated (indirect correlation) only with Al. The least squares simple regression was performed between the two variables and, after deleting unusual residuals, the function is presented in Eq. 3 (plotted in Fig. 4C). As it was the only possibility between the possible reference elements, this equation was selected as background function.

(Eq. 3) ThBG $=11.95-3.83 \cdot \mathrm{Al}(\mathrm{R}=0.82, \mathrm{n}=21$, Fig. $4 \mathrm{C})$ 
Table 3. Estimated background values as content (mean $\pm 2 \mathrm{SD}$, UCC and EC in $\mathrm{mg} \mathrm{kg}^{-1}$ ), also presented the element-to-aluminium ratios. References (UCC and EC) provided for comparison)

\begin{tabular}{|c|c|c|c|c|c|c|}
\hline & Mean $\pm 2 S D$ & UCC & $\mathrm{EC}$ & $\begin{array}{l}\mathrm{El} / \mathrm{Al} \\
\left(10^{-4}\right)\end{array}$ & $\begin{array}{l}U^{U C C_{E l} / A l} \\
\left(10^{-4}\right)\end{array}$ & $\begin{array}{l}\mathrm{EC}_{\mathrm{El} / \mathrm{Al}} \\
\left(10^{-4}\right)\end{array}$ \\
\hline$U$ & $8.66 \pm 1.92$ & 2.7 & 2 & $\begin{array}{l}5.53 \pm 1 \\
.03\end{array}$ & 0.33 & 0.24 \\
\hline Th & $5.61 \pm 2.17$ & $\begin{array}{l}10 . \\
5\end{array}$ & 12 & $\begin{array}{l}3.54 \pm 2 \\
.36\end{array}$ & 1.29 & 1.46 \\
\hline
\end{tabular}

UCC: upper continental crust reference (Rudnick and Gao, 2003) EC: Earth crust reference (Emsley, 2011)

By using the samples included in the regressions forming the background functions (Eqs. 2 and 3 ) the background estimation at a local scale in the area (mean \pm 2 standard deviation) was calculated to be $8.7 \pm 1.9 \mathrm{mgU} \mathrm{kg}-1$ and $5.6 \pm 2.2 \mathrm{mgTh} \mathrm{kg}-1$. Background information is compared with global (terrestrial crust) references in Table 3.

The local enrichment factors (LEFs; GRYGAR and POPELKA, 2016) for each sample were calculated according to Eq.4, where [El] is the element measured content in each sample and ElBG is the theoretical element content calculated according to the background function (Eq. 2 and 3). For both ( $U$ and Th) the median value for LEFs is 1.0 , indicating that the elements are not generally enriched in the area. Values significantly over the background (LEF > 1.5) are restricted to punctual samples, to wit, $U$ is enriched in the samples P01 (3.8), P08 (2.2) and P03 (1.8); Th is enriched in samples P03 (2.9), P09 (2.8), P04 (1.6) and P08 (1.6). The spatial distribution of LEFs is presented in Fig. 5.

(Eq. 4) LEF $=[E l] / E I B G$
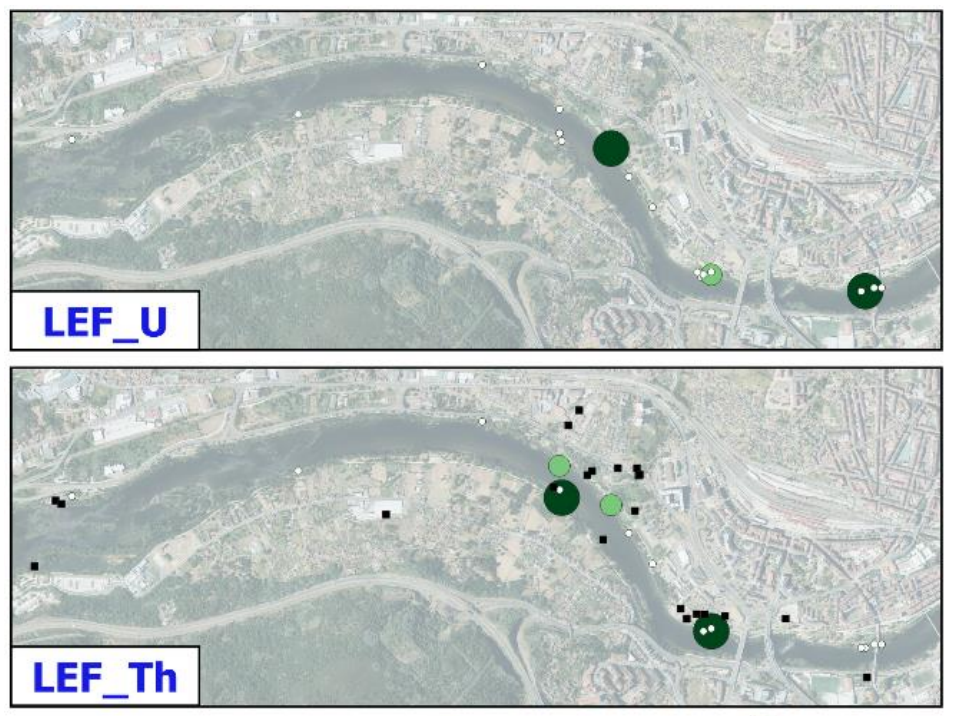

- Thermal springs

LEF $<1.5 \quad 1.5<$ LEF $<2.0$

LEF $>2.0$

Figure 5. Spatial distribution of local enrichment factors (LEFs) in the study site. Also presented location of thermal springs. Basemap from PNOA (IGN)

\section{Discussion}

The background results for $U(8.7 \pm 1.9 \mathrm{mg} \mathrm{kg}-1)$ are above the general references for the Earth crust and continental crust (see Table 3). However, they are coherent, i.e. inside the range measured, with the contents on GaliciaNorth Portugal granites (4.5-14.3 mg kg-1; LAMAS et al., 2017) and soils (4.8-29.2 mg kg-1; TABOADA et al., 2006). Conversely, Th contents $(5.6 \pm 2.2 \mathrm{mg} \mathrm{kg}-1)$ are below general references and slightly lower than the contents in local granites (9.1-21.0 mg kg-1; LAMAS et al., 2017), soils (7.4-56.7 mg kg-1; TABOADA et al., 2006), soils over sediments developed in variscan granites in Spain (21-831 mg kg-1; LOCUTURA RUPÉREZ et al., 2012) and, marine sediments $(9.4 \pm 5.1 \mathrm{mg} \mathrm{kg}-1$; MARMOLEJO-RODRÍGUEZ et al., 2008). Both elements has affinity for clay particles and use to be leached from soil surface, being accumulated in deeper horizons (TABOADA et al., 2006). Thus, the general contents of $U$ and Th can be explained by their presence in the bedrock and a loss by leaching processes within the sediments.

The results point to a different behaviour of the two elements. The correlation between $\mathrm{Al}$ and $\mathrm{U}$ (Fig. 3), also the background function (Eq. 2) indicate that clay (fine lithogenic) minerals may be the major driver controlling the $U$ contents in the samples. Aluminium is often used as a proxy for clay minerals (JICKELLS and RAE, 1997), for this reason it is commonly employed to normalize sediment contents of trace elements (e.g. ÁLVAREZVÁZQUEZ et al., 2020; PREGO et al., 2008). This reference element is also depleted in the samples $(1.6 \pm 0.3 \%)$ in comparison with local rocks (7.1-7.7 \%; BARRERA MORATE et al., 1989). Álvarez-Vázquez and De Uña-Álvarez (2021) hypothesised that, in bedrock rivers sediments, there is a loss of fine clay minerals, which are exported downstream. Thus, in the scarce fine fraction could be an important participation of materials from coatings and biofilms detached during drying-sieving from the sand surfaces, this fact could be supported by the high contents of $\mathrm{Mn}$ (median $0.3 \%$ ) in the studied fine fraction of sediments (Fig. 2). For comparison, Mn contents in estuarine sediments of rivers, in a close geographical area, were measured to be 10 times lower (ca. $0.03 \%$, ÁLVAREZ-VÁZQUEZ et al., 2017).

The differential behaviour of Th, indirectly correlated with $\mathrm{Al}$ (Fig. 3 and background function Eq.3) might be related with the late authigenic particles, as observed in marine sediments from the Ria of Vigo (NW Iberian Peninsula) where Th showed affinity for organic matter (MARMOLEJO-RODRÍGUEZ et al., 2008). Moreover, $U$ has a high mobility in water while Th is rapidly immobilized in oxigenic conditions (LOCUTURA RUPÉREZ et al., 2012). Comparing sedimentary microenvironments (FigBoxPlots), $\mathrm{U}$ is slightly enriched in potholes and rock cavities ( $\mathrm{P}$ and C), semienclosed systems that can retain fine particles, 
and Th is enriched in surface sediments ( $P$ and $R$ ) where sunlight (evaporation) and oxygen can favour the development of coatings and biofilms. Thus, lithogenic fine particles may be the major driver determining $U$ variability while authigenic processes within the depositional environment might be behind the variability of Th contents in the fine fraction of sediments. Besides, the negative correlation between Al and Th supports this idea, pointing to a different variability source. In the area, hydrothermal springs can be the differentiated source of $\mathrm{U}$ and Th; the disintegration of these elements can be an additional heat source in hydrothermal waters (López et al. 2019). While dissolved $U$ runs with the waterflow, the less mobile Th is subject to precipitation and/or adsorption on surfaces.

The contamination assessment due to the LEFs do not allow describing contamination by $\mathrm{U}$ and $\mathrm{Th}$ in the area. Notwithstanding, it is possible to talk about punctual localized enrichments, all of them in surface sediments retained in rock cavities. Uranium is enriched in incipient sculpted forms (P01, P08 and P03, low developed potholes and furrows) without capacity to retain permanent sediments (ÁLVAREZ-VÁZQUEZ and DE UÑA-ÁLVAREZ, 2017b) thus, they are temporary sediments retained after the last floods and dried by evaporation. For the enrichments of Th, the sculpted forms where they happen (P03, P09, and P04) are similar to those for U, but they are somehow related with the presence of thermal springs in the area (Fig. 5) described by Araujo Nesperaira et al. (2021). In this sense, Llerena et al. (2013) showed similar contribution of 238- $U$ and 232-Th in traditional springs; Th clearly dominates in the concentrations of spa waters. As previously indicated, Th has a low mobility, when released into the environment is rapidly immobilized by precipitation as oxide or phosphate, also by adsorption over clay minerals, hydroxides or organic matter (LOCUTURA RUPÉREZ et al., 2012). Thus, thermal springs would be behind a natural enrichment in certain sediments trapped into localized fluvial sculpted forms. Fig. 4 shows the Th-LEF and thermal springs spatial distribution. This interesting association between Th sediment contents and thermal waters has a good potential, if proven, as tracer of thermal influence in the fluvial environment. Notwithstanding, more research is needed in order to set its availability.

\section{Conclusions}

The application of least squares simple regression to sediments of the studied reach of the Miño River (Ourense

Spain) has showed success to estimate the natural background of $U$ and Th. The background functions were calculated by using $\mathrm{Al}$ as the most appropriate reference element after checking inter-element correlations. More than providing natural content reference values, the background functions are more suitable for comparison between similar areas. This background reference information for $\mathrm{U}$ and Th is provided for the first time in sediments of the Miño River. Both elements showed different variability patterns, $U$ is related with lithogenic clay minerals (fine particles) from bedrock weathering, while Th related to authigenic sink processes occurring in the rock cavities microenvironment. Thorium variations are suspected to be somehow related with thermal springs in the area, future research would rely in testing Th as a geochemical marker of thermal influence in the fluvial environment. The enrichments described in the area (both $\mathrm{U}$ and $\mathrm{Th}$ ) can be attributed to microscale processes inside fluvial sculpted forms, i.e. retention of fine particles for $\mathrm{U}$ and developing of biofilms for Th. Future works will be aimed to define the participation of organic matter and thermal springs in the sediment composition in bedrock rivers.

\section{REFERENCES}

ÁLVAREZ-VÁZQUEZ, M.Á.; DE UÑA-ÁLVAREZ, E. (2021). An exploratory study to test sediments trapped by potholes in Bedrock Rivers as environmental indicators (NW Iberian Massif). Cuaternario y Geomorfología, 35(1-2), 59-77. https://doi.org/10.17735/cyg.v35i1-2.89054

ÁLVAREZ-VÁZQUEZ, M.Á.; ÁLVAREZ-IGLESIAS, P.; DE UÑAÁlVAREZ, E.; QUINTANA, B.; CAETANO, M.; PREGO, R. (2020). Industrial supply of trace elements during the "Anthropocene": A record in estuarine sediments from the Ria of Ferrol (NW Iberian Peninsula). Marine Chemistry, 223, 103825. https://doi.org/10.1016/j.marchem.2020.103825

ADRIÁN RODRÍGUEZ, M. C., LÓPEZ GONZÁLEZ, M.; DE UÑA ÁLVAREZ, E. Geoheritage and cultural Heritage. The voice of sound Resonances in Waterfalls. (Cantara da Moura, NW Spain). En: INTERNATIONAL PROGEO SYMPOSIUM, 10th, 2021, Segovia. Building connections for global Geoconservation. Madrid: Ministerio de Ciencia e Innovación, Instituto Geológico y Minero de España, 2021. p. 259-260.

ÁLVAREZ-VÁZQUEZ, M.Á.; HOŠEK, M.; ELZNICOVÁ, J.; PACINA, J.; HRON, K.; FAČEVICOVÁ, K.; TALSKÁ, R.; BÁBEK, O.; GRYGAR, T.M. (2020). Separation of geochemical signals in fluvial sediments: New approaches to grain-size control and anthropogenic contamination. Applied Geochemistry, 123, 104791. https://doi.org/10.1016/j.apgeochem.2020.104791

ÁLVAREZ-VÁZQUEZ, M.Á.; DE UÑA-ÁLVAREZ, E. (2017a). Inventory and assessment of fluvial potholes to promote geoheritage sustainability (Miño River, NW Spain). Geoheritage, 9(4), 549-560. https://doi.org/10.1007/s12371-016-0213-0 
ÁLVAREZ-VÁZQUEZ, M.Á.; DE UÑA-ÁLVAREZ, E. (2017b). Growth of sculpted forms in bedrock channels (Miño River, northwest Spain). Current Science, 996-1002. https://doi.org/10.18520/cs/v112/i05/996-1002

ÁlVAREZ-VÁZQUEZ, M.Á.; CAETANO, M.; ÁlVAREZIGLESIAS, P.; PEDROSA-GARCÍA, M.C.; CALVO, S.; DE UÑAÁLVAREZ, E.; QUINTANA, B.; VALE, C.; PREGO, R. (2017). Natural and Anthropocene fluxes of trace elements in estuarine sediments of Galician Rias. Estuarine, Coastal and Shelf Science, 198, 329-342. https://doi.org/10.1016/j.ecss.2016.08.022

ARAUJO NESPERAIRA, P.A.; CID FERNÁNDEZ, J.A.; DELGADO OUTEIRIÑO, I.; GÜEZMES BARRIUSO, A.L. (2021) Inventario y caracterización del yacimiento termal de Ourense ciudad (Galicia, España). Xeoaquis. Accessed 1115-2021 from: http://www.xeoaquis.com/admin/docs/070501\%20YACl MIENTO\%20GEOTERMICO\%20OURENSE-CIUDAD.pdf

BARRERA MORATE, J.L., GONZÁLEZ LODEIRO, F., MARQUÍNEZ GARCÍA, J., MARTÍN PARRA, L.M., MARTÍNEZ CATALÁN, J.R., PABLO MACIÁ, J.G. (1989). Memoria del mapa geológico de España, Escala 1:200.000, Ourense/Verín. Instituto Tecnológico GeoMinero de España, Madrid, 284 p.

BIRCH, G.F. (2017). Determination of sediment metal background concentrations and enrichment in marine environments-a critical review. Science of the total environment, $\quad 580, \quad 813-831$. https://doi.org/10.1016/j.scitotenv.2016.12.028

DUNG, T.T.T.; CAPPUYNS, V.; SWENNEN, R.; PHUNG, N.K. (2013). From geochemical background determination to pollution assessment of heavy metals in sediments and soils. Reviews in Environmental Science and Bio/Technology, 12(4), 335-353. https://doi.org/10.1007/s11157-013-9315-1

GRYGAR, T. M.; POPELKA, J. (2016). Revisiting geochemical methods of distinguishing natural concentrations and pollution by risk elements in fluvial sediments. Journal of Geochemical Exploration, 170, 3957. https://doi.org/10.1016/j.gexplo.2016.08.003

ICON (2001). Pollutants in urban waste water and sewage sludge. European Commission. Luxenburg.

LAMAS, R.; MIRANDA, M.M.; PEREIRA, A.J.S.C.; NEVES, L.J.P.F.; FERREIRA, N.; RODRIGUES, N.V. (2017). 3-D distribution of the radioelements in the granitic rocks of Northern and Central Portugal and geoth $\epsilon$ implications. Cuadernos de geología ibérica $=$ Journal of iberian geology: an international publication of earth sciences, 43(1), 3-12.
LLERENA, J.J.; CORTINA, D.; DURÁN, I.; SORRIBAS, R. (2013). Impact of the geological substrate on the radiological content of Galician waters. Journal of environmental radioactivity, 116, 48-53. https://doi.org/10.1016/j.jenvrad.2012.08.014

LOCUTURA-RUPÉREZ, J.; BEL-IAN, A.; GARCÍA-COERTÉS, A.; MARTÍNEZ-ROMERO, S. (2012). Atlas Geoquímico de España. IGME, Madrid, $592 \mathrm{p}$.

LÓPEZ, D.L.; ARAUJO, P.A.; OUTEIRIÑO, I.D.; CID, J.A.; ASTRAY, G. (2019). Geochemical signatures of the groundwaters from Ourense thermal springs, Galicia, Spain. Sustainable Water Resources Management, 5(1), 103-116. https://doi.org/10.1007/s40899-018-0239-3

MARMOLEJO-RODRÍGUEZ, A. J.; CAETANO, M.; PREGO, R.; VALE, C. (2008). Thorium accumulation in the sedimentary environment of the Vigo Ria (NW Iberian Peninsula). Journal of environmental radioactivity, 99(10), 1631-1635. https://doi.org/10.1016/j.jenvrad.2008.06.008

PLANT, J.A.; SAUNDERS, A.D. (1996). The radioactive earth. Radiation Protection Dosimetry, 68(1-2), 25-36. https://doi.org/10.1093/oxfordjournals.rpd.a031847

PREGO, R.; FILGUEIRAS, A.V.; SANTOS-ECHEANDÍA, J. (2008). Temporal and spatial changes of total and labile metal concentration in the surface sediments of the Vigo Ria (NW Iberian Peninsula): Influence of anthropogenic sources. Marine pollution bulletin, 56(5), 1031-1042.

RUDNICK, R.L.; GAO, S. (2003). Composition of the Continental Crust. Treatise on Geochemistry, 3, 659.

SANTSCHI, P.H.; PRESLEY, B.J.; WADE, T.L.; GARCIAROMERO, B.; BASKARAN, M. (2001). Historical contamination of PAHs, PCBs, DDTs, and heavy metals in Mississippi river Delta, Galveston bay and Tampa bay sediment cores. Marine Environmental Research, 52, 5179. https://doi.org/10.1016/s0141-1136(00)00260-9

TABOADA, T.; CORTIZAS, A.M.; GARCÍA, C.; GARCÍARODEJA, E. (2006). Uranium and thorium in weathering and pedogenetic profiles developed on granitic rocks from NW Spain. Science of the Total Environment, 356(1-3), 192-206.

https://doi.org/10.1016/j.scitotenv.2005.03.030

WHIPPLE, K.X.; DIBIASE, R.A.; CROSBY, B.T. (2013). Bedrock rivers. Fluvial Geomorphology (pp. 550-573). Elsevier Inc. 